\title{
An EOQ model with Weibull Deterioration, Time Dependent Demand under Salvage Value
}

\author{
R Mohan \\ Asst. Professor, College of Military Engineering Pune-31
}

\begin{abstract}
This paper investigates an inventory model for deteriorating items under cost minimization with Weibull deterioration rate. The model is solved with salvages value associated in the system. A numerical example is taken to discuss the sensitivity of the models using Mathcad software.
\end{abstract}

Key words: Inventory, perishable, Weibull distribution, Deterioration

\section{Introduction}

Any inventory system deterioration of any item is a realistic phenomenon. It is realistic to note that a product may have a life time when the utility attain to zero. Researchers constantly developed deteriorating inventory models to become more realistic. Weibull distribution is articulated for many failure items. Covert and Philip (1973) studied an EOQ model for items with Weibull distribution deterioration. Hariga (1996) developed an Optimal EOQ models for deteriorating items with time-varying demand. Deb and Chaudhuri, (1986) presented an EOQ model for items with finite rate of production and variable rate of deterioration. Chung and Ting (1993) established an heuristic for replenishment of deterioration items with linear trend in demand. A single period inventory problem with quadratic demand distribution under the influence of market policies developed by Bhandari and Sharma (2000). The complete literature survey of models of inventory system the 'recent trends in modeling of deteriorating inventory' studied by Giri and Goyal (2001). Mondal et al (2003) proposed an inventory system of ameliorating items for price dependent demand rate. Ghosh and Chaudhuri (2004) developed an order- level inventory model for a deteriorating item with Weibull Deterioration, Timequadratic demand. They also incorporated shortages are allowed in the system. Kharna and Chaudhuri.(2003) presented a note on order-level inventory model for a deteriorating item with time-dependent quadratic demand. Sana and .Chaudhary (2004) developed a stock-review EOQ model with stock-dependent demand, quadratic deterioration rate. Kalam et al (2010) presented a production lot-size inventory model for Weibull deteriorating item with quadratic demand, quadratic production and shortages. Poonam Mishra and Shah (2008) investigates an EOQ model for inventory management of time dependent deteriorating items with salvage value. Ajanta Roy, (2008) studied an inventory model for deteriorating items with price dependent demand and time-varying holding cost. Mohan and Venkateswarlu (2013) proposed an inventory management models with variable holding cost and salvage value. This paper investigates time dependent demand with time varying holding cost under Weibull deterioration rate. Also salvage value is associated in this model for deteriorating items.

\section{Assumptions}

The mathematical model is developed on the following assumptions and notations:

(i) The selling rate $D(t)$ at time $t$ is assumed to be $D(t)=\mathrm{D}(\mathrm{t})=\mathrm{Rt}^{-\mathrm{p}} \quad \alpha>0,0<\mathrm{p}<1$.

(ii) The deterioration rate follows two parameter Weibull distribution and if given by $\theta(t)=\alpha \beta t^{\beta-1} ; 0 \leq \alpha$ $\leq 1, \beta \geq 1$.

(iii) Replenishment rate is infinite and lead time is zero.

(iv) $\mathrm{C}_{1}$, deterioration cost per unit item

(v) $p$, purchasing cost per unit item

(vi) R, the fixed opportunity cost of lost sales

(vii) A, the ordering cost per order is known and constant.

(vii) $I(t)$ is the inventory level at time $t$.

(viii) The salvage value $\gamma \mathrm{C}, 0 \leq \gamma<1$ is associated with deteriorated units during a cycle time.

\section{Formulation and solution of the model}

The objective of the model is to determine the minimum total cost for items having time dependent quadratic demand, time dependent deterioration rate and salvage value. The inventory level depletes as the time passes due to selling rate and deterioration. The differential equation which describes the inventory level at time $\mathrm{t}$ can be written as 
$\frac{\mathrm{d}(\mathrm{t})}{\mathrm{dt}}+\theta(\mathrm{t}) \mathrm{I}(\mathrm{t})=-\mathrm{Rt}^{-\mathrm{p}} ; \theta=\alpha \beta \mathrm{t}^{\beta-1} \quad 0 \leq \mathrm{t} \leq \mathrm{r}$

with $I(t)=0 \quad$ at $t=\mathrm{T}$.

The solution of the above differential equation using the boundary conditions is given by

$$
\mathrm{I}(\mathrm{t})=\mathrm{R}\left(1-\alpha \mathrm{t}^{\beta}\right)\left\{\frac{1}{1-\mathrm{p}}\left(\mathrm{T}^{1-\mathrm{p}}-\mathrm{t}^{1-\beta}\right)+\frac{\alpha}{1+\beta-\mathrm{p}}\left(\mathrm{T}^{\beta+1-\mathrm{p}}-\mathrm{t}^{\beta+1-\mathrm{p}}\right)\right\}
$$

Since $\mathrm{I}(0)=\mathrm{q}$, we get

$\mathrm{q}=\mathrm{R}\left[\frac{\mathrm{T}^{1-\mathrm{p}}}{1-\mathrm{p}}+\frac{\mathrm{T}^{\beta+1-\mathrm{p} * \alpha}}{\beta+1-\mathrm{p}}\right]$

In the time interval $[0, \mathrm{~T}]$ the average inventory is given by

$\mathrm{I}_{1}(\mathrm{~T})=\int_{0}^{\mathrm{T}} \mathrm{I}(\mathrm{t}) \mathrm{dt}=\mathrm{R}\left[\frac{\mathrm{T}^{2-\mathrm{p}}}{2-\mathrm{p}}+\frac{\alpha^{*} \beta * \mathrm{~T}^{\beta+2-\mathrm{p}}}{(\beta+1)(\beta+2-\mathrm{p})}\right]$

The total cost per unit time (TC) consists of the following costs.

Ordering cost $(\mathrm{OC})=\mathrm{A}$

(i) Holding cost $(\mathrm{HC})==\int_{0}^{\mathrm{T}}(\mathrm{h}+\mathrm{rt}) \mathrm{I}(\mathrm{t}) \mathrm{dt}$

$\mathrm{HC}=\mathrm{R} * \mathrm{~h}\left[\left(\frac{\mathrm{T}^{2-\mathrm{p}}}{2-\mathrm{p}}+\frac{\beta * \alpha^{*} \mathrm{~T}^{2+\beta-\mathrm{p}}}{(\beta+1)(2+\beta-\mathrm{p})}\right)\right]+\mathrm{r} * \mathrm{R}\left[\frac{\mathrm{T}^{4-\mathrm{p}}}{2(2-\mathrm{p})}+\frac{\beta * \alpha^{*} \mathrm{~T}^{4+\beta-\mathrm{p}}}{2(\beta+2)(2+\beta-\mathrm{p})}\right]$

The Purchasing cost (PC), Cost due to deterioration (CD) and Salvage Value (SV) are calculated as

Purchasing cost (PC)

$$
p \mathrm{I}(0)=\mathrm{R} * \mathrm{p}\left[\left(\frac{\mathrm{T}^{1-\mathrm{p}}}{1-\mathrm{p}}+\frac{\alpha^{*} \mathrm{~T}^{1+\beta-\mathrm{p}}}{(1+\beta-\mathrm{p})}\right)\right]
$$

The number of deteriorated items during one cycle time is given by

$\mathrm{NDU}=\mathrm{q}-\int_{0}^{\mathrm{T}} \mathrm{I}(\mathrm{t}) \mathrm{dt}$
$=\frac{\mathrm{R} * \alpha \mathrm{T}^{1+\beta-\mathrm{p}}}{1+\beta-\mathrm{p}}$

Cost due to deterioration $(\mathrm{CD})=\mathrm{C}_{1} * \frac{\mathrm{R} * \alpha * \mathrm{~T}^{1+\beta-\mathrm{p}}}{1+\beta-\mathrm{p}}$

Salvage Value, $(\mathrm{SV})=$ 


$$
=\gamma \mathrm{p} * \frac{\mathrm{R} * \alpha * \mathrm{~T}^{1+\beta-\mathrm{p}}}{1+\beta-\mathrm{p}}
$$

The average total cost per unit time of the system will be

$$
\text { i.e., } \mathrm{TC}=\mathrm{PC}+\mathrm{OC}+\mathrm{HC}+\mathrm{CD}-\mathrm{SV}
$$

$$
\mathrm{TC}=\frac{1}{\mathrm{~T}}\left\{\begin{array}{l}
\mathrm{R} * \mathrm{p}\left[\left(\frac{\mathrm{T}^{1-\mathrm{p}}}{1-\mathrm{p}}+\frac{\alpha * \mathrm{~T}^{1+\beta-\mathrm{p}}}{(1+\beta-\mathrm{p})}\right)\right]+\mathrm{R} * \mathrm{~h}\left[\left(\frac{\mathrm{T}^{2-\mathrm{p}}}{2-\mathrm{p}}+\frac{\beta * \alpha * \mathrm{~T}^{2+\beta-\mathrm{p}}}{(\beta+1)(2+\beta-\mathrm{p})}\right)\right] \\
+\mathrm{r} * \mathrm{R}\left[\frac{\mathrm{T}^{4-\mathrm{p}}}{2(2-\mathrm{p})}+\frac{\beta * \alpha * \mathrm{~T}^{4+\beta-\mathrm{p}}}{2(\beta+2)(2+\beta-\mathrm{p})}\right]+\mathrm{C}_{1} * \frac{\mathrm{R}^{*} \alpha * \mathrm{~T}^{1+\beta-\mathrm{p}}}{1+\beta-\mathrm{p}}+\mathrm{A} \\
-\gamma \mathrm{p} * \frac{\mathrm{R} * \alpha * \mathrm{~T}^{1+\beta-\mathrm{p}}}{1+\beta-\mathrm{p}}
\end{array}\right\}
$$

The necessary condition for $\mathrm{TC}$ to be minimum is $\frac{\partial(T C)}{\partial T}=0$ and $\frac{\partial^{2} \mathrm{TC}}{\partial \mathrm{T}^{2}}>0$., i.e,

$$
\frac{\partial^{2}(\mathrm{TC})}{\partial \mathrm{T}^{2}}=\left\{\begin{array}{l}
\frac{\mathrm{p} * \mathrm{Rp}(\mathrm{p}+1) \mathrm{T}^{-2-\mathrm{p}}}{1-\mathrm{p}}+\frac{\mathrm{h}^{*} \mathrm{R} * \mathrm{p}(1-\mathrm{p}) \mathrm{T}^{-\mathrm{p}-1}}{2-\mathrm{p}} \\
+\frac{\mathrm{h}^{*} \mathrm{R} * \alpha \beta(\beta+-\mathrm{p})(\beta-\mathrm{p}) \mathrm{T}^{-\mathrm{p}+\beta-1}}{(\beta+1)(\beta+2-\mathrm{p})} \\
+\mathrm{R} * \mathrm{r}\left[\frac{(4-\mathrm{p})(3-\mathrm{p}) \mathrm{T}^{2-\mathrm{p}}}{\alpha(2-\mathrm{p})}+\frac{(4+\beta-\mathrm{p})(3+\beta-\mathrm{p}) \mathrm{T}^{2+\beta-\mathrm{p}}}{2(1+\beta)(2+\beta-\mathrm{p})}\right.
\end{array}\right]>0
$$

The inventory model for linear demand when the deterioration follows Weibull distribution and salvage value is obtained by substituting $a=0$ and further reduces to constant demand inventory model when $a=b=0$. In this case the model reduces to that of Mishra and Shah (2007).

\section{Numerical Example}

To illustrate the models developed, we assume the following data:

$$
R=1000 \quad r=.3 \quad A=50 \quad C 1=0.1
$$

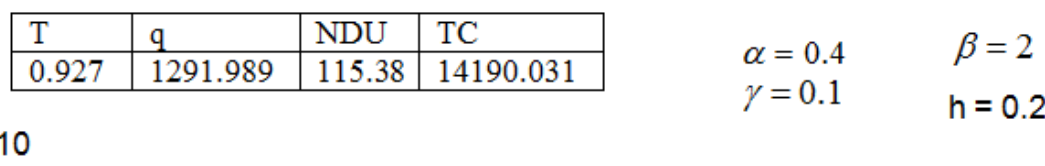

Using sensitivity analysis we can further analyze the significance of the model.

\section{Conclusions}

An economic order quantity model for time dependent demand under weibull deterioration with salvage value is developed. Shortages are not allowed in this model. Numerical example using MathCad software is also given. 


\section{References}

[1]. Covert, R. P., and Philip, G.C., (1973), An EOQ model for items with Weibull distribution deterioration. AIIE Transactions, 5,323326

[2]. Hariga, M. (1996), Optimal EOQ models for deteriorating items with time-varying demand. Journal of Operational Research Society, $47,1228-1246$

[3]. Deb M and Chaudhuri, K.S. (1986) An EOQ model for items with finite rate of production and variable rate of deterioration. Opsearch, 23,175-181.

[4]. Chung, . and Ting, P. (1993), An heuristic for replenishment of deterioration items with linear trend in demand. Journal of Operational Research Society,44, 1235-1241

[5]. R.M.Bhandari and P.K.Sharma (2000) A single period inventory problem with quadratic demand distribution under the influence of Market policies', Eng. Science Vol. 12. No.2, pp. 117-127.

[6]. B.C.Giri and S.K.Goyal., (2001), 'Recent trends in modeling of deteriorating inventory' European Journal of Operations research, Vol.134, pp.1-16.

[7]. B. Mondal, A. K . Bhunia, and M Maiti.,(2003), An inventory system of ameliorating items for price dependent demand rate. Computers and Industrial Engineering, 45(3), 443-456.

[8]. S.K.Ghosh and K.S.Chaudhuri (2004) 'An order- level inventory model for a deteriorating item with Weibull Deterioration, Timequadratic demand and shortages", Advanced Modeling and Optimization, Vol.6, No.1, pp.21-35.

[9]. S.Kharna and K.S.Chaudhuri.(2003) 'A note on order-level inventory model for a deteriorating item with time-dependent quadratic demand' Computers and Operations research, Vol.30, pp.1901-1916.

[10]. Shibshankar Sana and K.S.Chaudhary (2004) A Stock-Review EOQ Model with Stock-Dependent Demand, Quadratic Deterioration Rate', Advanced Modeling and Optimization, vol.6, No.2, pp 25-32.

[11]. A. Kalam, D. Samal, S. K. Sahu \& M. Mishra (2010) A Production Lot-size Inventory Model for Weibull Deteriorating Item with Quadratic Demand, Quadratic Production and Shortages, International Journal of Computer Science \& Communication, Vol. 1, No. 1, Jan. 2010, pp. 259-262

[12]. Poonam Mishra and Nita H.Shah (2008) Inventory Management of Time Dependent Deteriorating Items with Salvage Value, Applied Mathematical sciences, Vol.2, No.16, pp793.

[13]. Ajanta Roy, (2008), An inventory model for deteriorating items with price dependent demand and time-varying holding cost, AMO Vol 10, Number 1

[14]. Mohan R and Venkateswarlu R (2013)., Inventory Management Models with Variable holding and Salvage Value, IOSR J. of Busi. and Mgmt (IOSR-JBM), Vol.12(3), pp. 37-42 .

R. Mohan. "An EOQ model with Weibull Deterioration, Time Dependent Demand under Salvage Value." IOSR Journal of Mathematics (IOSR-JM) 13.3 (2017): 39-42. 